\title{
Integrated assessment of biomarker responses in algae Chlorella sorokiniana exposed to copper and cadmium
}

\author{
TITI HAYATI RAHAYU, ANDHIKA PUSPITO NUGROHO \\ Faculty of Biology, Universitas Gadjah Mada. Jl. Teknika Selatan, Sekip Utara, Sleman 55281, Yogyakarta, Indonesia. Tel./fax.: +62-274-580839, \\ "email: andhika_pn@ugm.ac.id, titihayatirahayu@ugm.ac.id
}

Manuscript received: 13 January 2020. Revision accepted: 14 July 2020.

\begin{abstract}
Rahayu TH, Nugroho AP. 2020. Integrated assessment of biomarker responses in algae Chlorella sorokiniana exposed to copper and cadmium. Biodiversitas 21: 3569-3575. Microalgae Chorella as a major producer in aquatic ecosystems has high probability of being exposed to metal pollutants. Metal exposure to algae can induce the formation of reactive oxygen species (ROS), leading to oxidative stress states. ROS trigger the responses of biomarkers of antioxidative enzymes, including superoxide dismutase (SOD), catalase (CAT), and ascorbate peroxidase (APX). This study aims to develop an integrated biomarker response index and star plot for interpretation of the antioxidative enzyme responses in Chlorella sorokiniana. The microalgae were exposed to three concentrations of copper $(\mathrm{Cu})$ and cadmium $(\mathrm{Cd})$ for $48 \mathrm{~h}$, respectively. The results showed that exposure to $\mathrm{Cu}$ and $\mathrm{Cd}$ caused an increase of protein content and activities of SOD and APX. Analysis of integrated biomarker response (IBR) showed a decrease in the value of IBR along with an increase in cadmium concentration but no similar pattern found in copper. The multiple factor analysis (MFA) approach showed that exposure to $\mathrm{Cu} 0.3 \mu \mathrm{mol} \mathrm{L}-1$ for $48 \mathrm{~h}$ had high score of protein content and SOD activity in the first dimension. For the second dimension, exposure to $\mathrm{Cu} 1.6 \mu \mathrm{mol} \mathrm{\textrm {L } ^ { - 1 }}$ for $6 \mathrm{~h}$ had high score of APX and SOD activity.
\end{abstract}

Keywords: Antioxidative responses, Chlorella sorokiniana, integrated biomarker responses, metal, multiple factor analysis, star plot

\section{INTRODUCTION}

Freshwater microalgae such as Chlorella are used in environmental toxicology studies because of their abundant quantity, short life cycle, easy to be cultured, and sensitive to metal contaminants at environmentally realistic levels (Wang et al. 2018). $\mathrm{Cu}$ and $\mathrm{Cd}$ represent metals that generally pollute aquatic ecosystems and can cause toxic effects on aquatic organisms. $\mathrm{Cu}$ is an important micronutrient for plants and algae. It is a component of proteins and enzymes involved in various metabolic pathways (Elisabetta and Gioacchino 2004). However, it can be toxic at high concentrations (Chang and Sibley 1993). Cd is a non-essential element and toxic to humans, animals, and plants even in low concentrations.

In algae, metals stimulate defense mechanisms through the production of non-enzymatic and enzymatic antioxidants (Dat et al. 2000). Non-enzymatic antioxidants include glutathione, phenol, and ascorbate, while enzymatic defenses include superoxide dismutase (SOD), catalase (CAT) and ascorbate peroxidase (APX). SOD catalyzes the conversion of superoxide $\left(\mathrm{O} 2 \bullet^{-}\right)$to peroxide $\left(\mathrm{H}_{2} \mathrm{O}_{2}\right)$, while APX and CAT enzymes catalyze the reduction of $\mathrm{H}_{2} \mathrm{O}_{2}$ to $\mathrm{H}_{2} \mathrm{O}$ and $\mathrm{O}_{2}$ (Bhattacharjee 2005). Those antioxidants are called biomarker responses because antioxidants are produced as one of the responses of algae when they are exposed to pollutants such as metal.

A common challenge in multi-biomarker studies is to go beyond an independent interpretation of each one, and to assess the global response of individual biomarkers. This global assessment also simplifies their interpretation of biomonitoring programs. Among the indices proposed to integrate individual biomarker responses, the most popular is the Integrated Biomarker Response (IBR) initially proposed by Beliaeff and Burgeot (2002). The IBR approach is a method that provides both a graphical synthesis of the different biomarker responses and a numeric value that integrates all these responses at once (Devin et al. 2014). This study aims to develop an integrated biomarker response index and star plot for interpretation of the antioxidative enzyme responses in Chlorella sorokiniana.

\section{MATERIALS AND METHODS}

\section{Culture condition and experimental design}

The freshwater algae Chlorella sorokiniana Shirira et Krauss was provided by Ugo Plankton Laboratory which is located in Purworejo, Central Java. It was grown in axenic conditions at $23^{\circ} \mathrm{C}$, under continuous illumination (1200 $\mu \mathrm{mol} \mathrm{m} \mathrm{m}^{-2} \mathrm{~s}^{-1}$ light intensity), and in Guillard $\mathrm{F} / 2$ medium (Sandoval et al. 2015). Guillard F/2 medium consists of macronutrients $\left(\mathrm{NaH}_{2} \mathrm{PO}_{4} \cdot \mathrm{H}_{2} \mathrm{O}\right), \quad$ micronutrients $\left(\mathrm{FeCl}_{3} .6 \mathrm{H}_{2} \mathrm{O}, \quad \mathrm{Na}_{2}\right.$ EDTA. $2 \mathrm{H}_{2} \mathrm{O}, \quad \mathrm{MnCl}_{2} .4 \mathrm{H}_{2} \mathrm{O}$, $\mathrm{ZnSO}_{4} .7 \mathrm{H}_{2} \mathrm{O}, \mathrm{CoCl}_{2} \cdot 6 \mathrm{H}_{2} \mathrm{O}, \mathrm{CuSO}_{4} .5 \mathrm{H}_{2} \mathrm{O}, \mathrm{Na}_{2} \mathrm{MoO}_{4} .2 \mathrm{H}_{2} \mathrm{O}$ ) and vitamins (thiamine $\mathrm{HCl}$, biotin, cyanocobalamin). To test the effect of $\mathrm{Cu}$ and $\mathrm{Cd}$, stock solution was prepared by dissolving $\mathrm{CuCl}_{2} .2 \mathrm{H}_{2} \mathrm{O}$ and $3 \mathrm{CdSO}_{4} .8 \mathrm{H}_{2} \mathrm{O}$, respectively.

For testing the effects of $\mathrm{Cu}$ and $\mathrm{Cd}$, into each 1-L culture bottle containing $750 \mathrm{~mL}$ algal culture with the density of $6.9 \times 10^{6}$ cell $\mathrm{mL}^{-1}$.) was added $\mathrm{Cu}$ and $\mathrm{Cd}$ from 
a stock solution, respectively, to establish the concentrations of $\mathrm{Cu}$, i.e. $0.3,1.6$, and $15.7 \mu \mathrm{mol} \mathrm{L}^{-1}$, and Cd, i.e. $0.2,0.9$, and $8.9 \mu \mathrm{mol} \mathrm{L^{-1 }}(\mathrm{n}=3)$. Three culture bottles were used as controls. At $0,2,6,24$, and $48 \mathrm{~h}$ after the addition of $\mathrm{Cu}$ and $\mathrm{Cd}, 100 \mathrm{~mL}$ aliquots were transferred into two $50-\mathrm{mL}$ polypropylene tubes for analysis of enzymatic antioxidants.

\section{Enzyme extraction}

Enzyme extraction was conducted by modified method of Moussa et al (2017). Algae was centrifuged at $4500 \mathrm{~g}$ for $5 \mathrm{~min}$, then the pellet was added with phosphate-buffered saline and centrifuged at $4500 \mathrm{rpm}$ for $5 \mathrm{~min}$. Pellet was put into $2 \mathrm{~mL}$ microtube of known weight then weighed to measure fresh weight. Fresh algae were crushed five times using liquid nitrogen and added protease inhibitor solution each one $\mathrm{mL}$ of volume. Protease inhibitor solution was made from mixture of $50 \mathrm{~g}$ of protease inhibitor for each 50 $\mathrm{mL}$ aquabidest. This mixture was centrifuged at $11000 \mathrm{~g}$ for $5 \mathrm{~min}\left(4^{\circ} \mathrm{C}\right)$. The supernatant was used for analyzing protein, superoxide dismutase (SOD), catalase (CAT), and ascorbate peroxidase (APX) activity assays.

\section{Protein analysis}

Protein analysis was conducted following the method of Lowry et al (1951) by reacting $300 \mu \mathrm{L}$ supernatant to 300 $\mu \mathrm{L}$ of Lowry D reagent then vortexed for $15 \mathrm{sec}$. Lowry D reagent was made in commercial laboratory (CV ChemMix Pratama Jogjakarta). Sample of mixture was incubated for $10 \mathrm{~min}$, reacted to $900 \mu \mathrm{L}$ of Lowry $\mathrm{E}$ reagent then vortex for $30 \mathrm{sec}$. Then, the mixture was incubated for 45 min, and the absorbance was read using a spectrophotometer at $\lambda 750 \mathrm{~nm}$.

\section{Superoxide dismutase analysis}

Analysis of SOD activity was conducted following the method of Marklund and Marklund (1974) in Kim et al (2017). This method reacted $1 \mathrm{~mL}$ of Tris- $\mathrm{HCl}$ buffer $(\mathrm{pH}$ 8.2) with $1 \mathrm{~mL}$ of aquabidest and $15 \mu \mathrm{L}$ of algae extract supernatant and added with $10 \mu \mathrm{L}$ of pyrogallol $2 \mathrm{mM}$. Absorbance measurements were performed with a spectrophotometer using a wavelength of $470 \mathrm{~nm}$ with time intervals of $3 \mathrm{~min}$. Blank solutions were combination of pyrogallol and aquabidest (ratio 1: 1). The measured data were expressed as units per milligram of protein (1 unit was the amount of enzyme utilized to inhibit 50\% of pyrogallol auto-oxidation per minute).

\section{Catalase analysis}

Catalase activity was measured according to modified Aebi and Lester (1984) method in Kasmiyati (2016). A total of $1.99 \mathrm{~mL}$ of phosphate buffer solution $50 \mathrm{mM} \mathrm{pH}$ 7.0 and $10 \mu \mathrm{L}$ of supernatant sample was mixed. One milliliter of $\mathrm{H}_{2} \mathrm{O}_{2}$ solution ( $3 \%$ concentration) was added to mixture then incubated for a minute. Catalase enzyme activity was measured by a UV-VIS spectrophotometer at wavelength of $240 \mathrm{~nm}$ for $3 \mathrm{~min}$ (one-minute interval). Value of $\mathrm{H}_{2} \mathrm{O}_{2}$ extension coefficient is $40 \mathrm{mM} \mathrm{cm}^{-1}$. Enzyme activity is expressed in $\mu \mathrm{mol} \mathrm{H}_{2} \mathrm{O}_{2}$ gram $^{-1}$ fresh weight. Fresh weight of algae was determined by harvesting algae using centrifuge at $11000 \mathrm{~g}$ for $5 \mathrm{~min}$ $\left(4^{\circ} \mathrm{C}\right)$ then they were weighed.

\section{Ascorbate peroxidase analysis}

APX activity was conducted following the method of Nakano and Asada (1981) with modification. A mixture of $1.3 \mathrm{~mL}$ potassium phosphate buffer $0.05 \mathrm{mM} \mathrm{pH} 7.8$ contained $0.1 \mathrm{mM}$ EDTA was reacted with $10 \mu \mathrm{L}$ supernatant, $800 \mu \mathrm{L} 0.5 \mathrm{mM}$ ascorbate and $800 \mu \mathrm{L} \mathrm{H}_{2} \mathrm{O}_{2}$ (3\% concentration). Those were incubated for a minute then the decrease in absorbance was measured for $3 \mathrm{~min}$ (one-minute interval) at $\lambda \quad 290 \mathrm{~nm}$ using a spectrophotometer. The collected data were used to define the reaction rate for $\mathrm{H}_{2} \mathrm{O}_{2}$ independent of ascorbate oxidation.

\section{Statistical analysis}

Analysis of variance (ANOVA) test was carried out to identify significant difference between metal concentration and exposure time to enzyme activity. Then data were analyzed using Duncan (DMRT) test to compare differences between two independent groups when the dependent variable is either ordinal or continuous.

Integrated Biomarker Response (IBR) was calculated using four selected biomarkers of $C$. sorokiniana: protein content, SOD, CAT, and APX activities. Briefly, the mean value $\left(\mathrm{X}_{\mathrm{i}}\right)$, the general mean $\left(\mathrm{m}_{\mathrm{i}}\right)$, and standard deviation $\left(\mathrm{SD}_{\mathrm{i}}\right)$ for each biomarker at each exposure condition were calculated (Iturburu et al. 2018). The value $X_{i}$ was then standardized to obtain $\mathrm{Y}_{\mathrm{i}}$, where $\mathrm{Y}_{\mathrm{i}}=\left(\mathrm{X}_{\mathrm{i}}-\mathrm{m}_{\mathrm{i}}\right) / \mathrm{SD}_{\mathrm{i}}$. Subsequently, $Z_{i}=-Y_{i}$ or $Z_{i}=Y_{i}$ were computed in the case of a biological effect corresponding. The minimum value (mini) of $Z_{i}$ for each biomarker was obtained for each exposure condition. Finally, the score $S$ was calculated as $\mathrm{S}_{\mathrm{i}}=\mathrm{Z}_{\mathrm{i}}+\mid$ mini $\mid$, where $\mid$ mini $\mid$ is the absolute value. These $\mathrm{S}$ values thus represented the gradient of values for each biomarker in different exposure conditions, with highest values corresponding to the highest biological effects. The integrated biomarker response for each condition was calculated via the following formula:

$$
\mathrm{IBR}=\mathrm{S} 1 * \frac{S 2}{2}+\mathrm{S} 2 * \frac{S 3}{2}+\ldots . \mathrm{Sn}-1 * \frac{S n}{2}+\mathrm{Sn} * \frac{S 1}{2}
$$

In which, the obtained score for each biomarker $\left(\mathrm{S}_{\mathrm{i}}\right)$ was multiplied with the score of the next biomarker $\left(\mathrm{S}_{\mathrm{i}}+1\right)$, arranged as a set, dividing each calculation by 2 and adding-up of all values (Devin et al. 2014, Iturburu et al. 2018)

Multiple Factor Analysis (MFA) is a multivariate data analysis method for summarizing and visualizing a complex data table in which individuals are described by several sets of variables (quantitative and /or qualitative) structured into groups (Pagès 2002). Its goal is to analyze several data sets of variables collected on the same set of observations, or - as in its dual version-several sets of observations measured on the same set of variables ( $\mathrm{L}^{\wedge} \mathrm{e}$ and Pages 2010). Exploratory data analyses were performed using $\mathrm{R}$ software with the FactoMineR package: 
https://cran.r-project.org/web/packages/FactoMineR/ (Le et al. 2008).

\section{RESULTS AND DISCUSSION}

\section{Results}

\section{Protein content}

Exposure to $\mathrm{Cu}$ and $\mathrm{Cd}$ resulted in significant increase of soluble protein content $(\mathrm{p}<0.05)$ (Figure 1). Exposure time $(0,2,6,24,48 \mathrm{~h})$ of $\mathrm{Cu}$ and $\mathrm{Cd}$ also showed significant difference on protein contents of $C$. sorokiniana $(\mathrm{p}<0.05)$. The results of post hoc DMRT test was shown in Tables 1 and 2 .

\section{Activity of antioxidative enzymes}

Exposure to $\mathrm{Cu}$ and $\mathrm{Cd}$ also had significant effects on superoxide dismutase and ascorbate peroxidase activities $(\mathrm{p}<0.05)$, but for catalase activity was not significant $(\mathrm{p}=0.054)$. Based on Figures 2-4, there were increasing activities of each treatment if compared to controls.

\section{Biomarker responses}

This study was conducted to understand effects of copper and cadmium on enzymatic antioxidants of $C$. sorokiniana. The calculation for copper and cadmium consisted of 4 biomarkers (B): Protein content, SOD, CAT, and APX enzyme activities. The value of $B$ was based on standard deviation of each variable without using statistical calculations (Table 3). The four B values were then integrated into one IBR value for each concentration. IBR value for $\mathrm{Cu}$ ranged from 2.34 to 2.74 (shown in Figure 5 A-C). IBR value for Cd ranged from 2.49 to 2.54 (shown in Figure 5. D-F).

\section{Multiple factor analysis}

This analysis was divided into one supplementary group and two active groups (Figures 6-8). Red color referred to active groups of variables and green color was supplementary groups of variables (Figure 11). There were two dimensions, the first dimension/Dim 1 (44.4\%) and the second dimension/Dim 2 (29.35\%). Dimensions counted for variations in component analysis based on eigenvalues (Matus et al. 1999). Coordinates between two active groups in the first dimension differed slightly whereas in the second dimension (Dim 2) there was only one group of variables namely enzyme activity (enzyme output). It had significant contribution to the second dimension. Briefly, Figure 7 showed the relationship between variables, quality of the representation of variables, as well as, the correlation between variables, and the dimensions.

Table 1. Significance of $\mathrm{Cd}$ and $\mathrm{Cd}$ concentration to protein content based on post hoc DMRT test

\begin{tabular}{lc}
\hline \multicolumn{1}{c}{ Treatments } & Protein content $\left(\mathbf{m g ~ g r a m}^{-1}\right)$ \\
\hline Control & $0.076^{\mathrm{a}}$ \\
$\mathrm{Cu} 0.3 \mu \mathrm{mol} \mathrm{L}$ & $0.159^{\mathrm{ab}}$ \\
$\mathrm{Cu} 1.6 \mu \mathrm{mol} \mathrm{L}^{-1}$ & $0.305^{\mathrm{ab}}$ \\
$\mathrm{Cu} 15.7 \mu \mathrm{mol} \mathrm{L}^{-1}$ & $0.333^{\mathrm{b}}$ \\
$\mathrm{Cd} 0.2 \mu \mathrm{mol} \mathrm{L}^{-1}$ & $0.368^{\mathrm{b}}$ \\
$\mathrm{Cd} 0.9 \mu \mathrm{mol} \mathrm{L}^{-1}$ & $0.374^{\mathrm{b}}$ \\
$\mathrm{Cd} 8.9 \mu \mathrm{mol} \mathrm{L}^{-1}$ & $0.385^{\mathrm{b}}$ \\
\hline
\end{tabular}

Note: ${ }^{\text {abc) }}$ Different letters show significant differences between treatments

Table 2. Significance of $\mathrm{Cd}$ and $\mathrm{Cd}$ exposure time to protein content based on post hoc DMRT test

\begin{tabular}{cc}
\hline Hour & Protein content $\left(\mathbf{m g ~ g r a m}^{-1}\right)$ \\
\hline 0 & $0.096^{\mathrm{a}}$ \\
2 & $0.133^{\mathrm{a}}$ \\
6 & $0.219^{\mathrm{ab}}$ \\
24 & $0.349^{\mathrm{b}}$ \\
48 & $0.631^{\mathrm{c}}$ \\
\hline
\end{tabular}

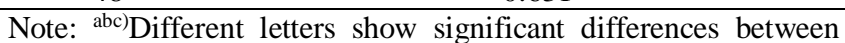
treatments

Table 3. B value of Chlorella sorokiniana exposed to $\mathrm{Cu}$ and $\mathrm{Cd}$

\begin{tabular}{|c|c|c|c|c|c|}
\hline \multirow{2}{*}{$\begin{array}{c}\text { Treatments } \\
\left(\mu \mathrm{mol} \mathrm{L} \mathbf{L}^{-1}\right)\end{array}$} & \multicolumn{4}{|c|}{ B value } & \multirow{2}{*}{ IBR } \\
\hline & Protein & SOD & CAT & APX & \\
\hline $\mathrm{Cu} 0.3$ & 0.650 & 0.592 & 0.524 & 0.574 & 2.34 \\
\hline $\mathrm{Cu} 1.6$ & 0.715 & 0.696 & 0.654 & 0.672 & 2.74 \\
\hline $\mathrm{Cu} 15.7$ & 0.698 & 1.345 & 0.654 & 0.679 & 2.38 \\
\hline $\mathrm{Cd} 0.2$ & 0.619 & 0.576 & 0.650 & 0.698 & 2.54 \\
\hline Cd 0.9 & 0.605 & 0.558 & 0.648 & 0.702 & 2.51 \\
\hline Cd 8.9 & 0.498 & 1.025 & 0.490 & 0.476 & 2.49 \\
\hline
\end{tabular}




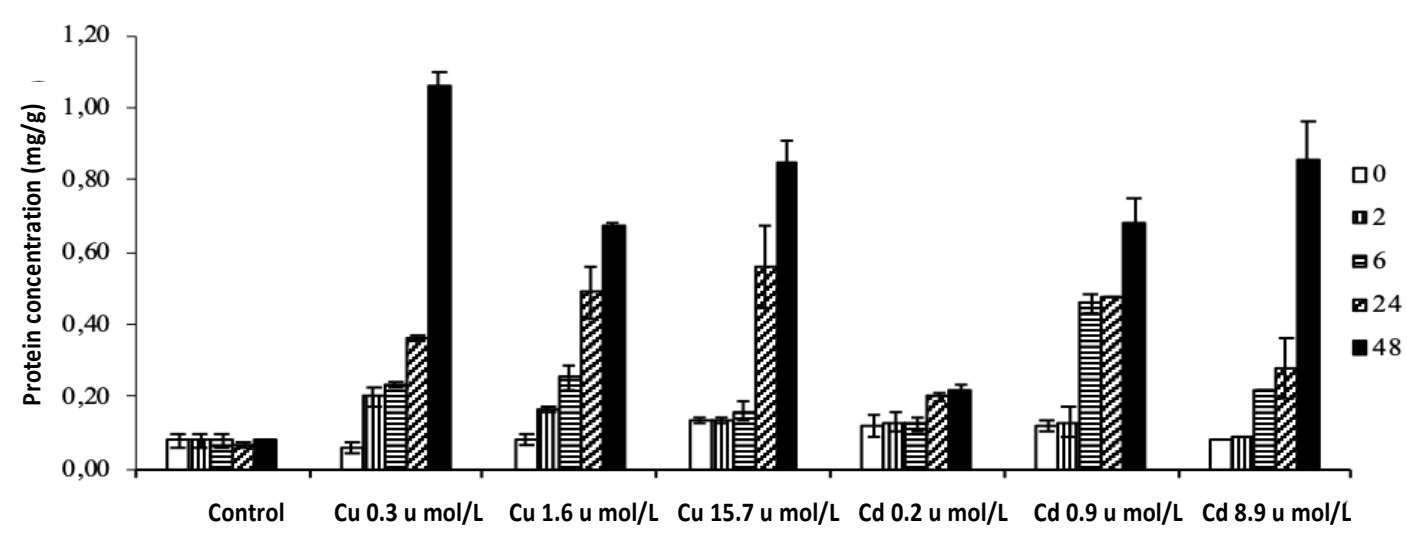

Figure 1. Protein content of Chlorella sorokiniana after exposure to $\mathrm{Cu}$ and $\mathrm{Cd}$.

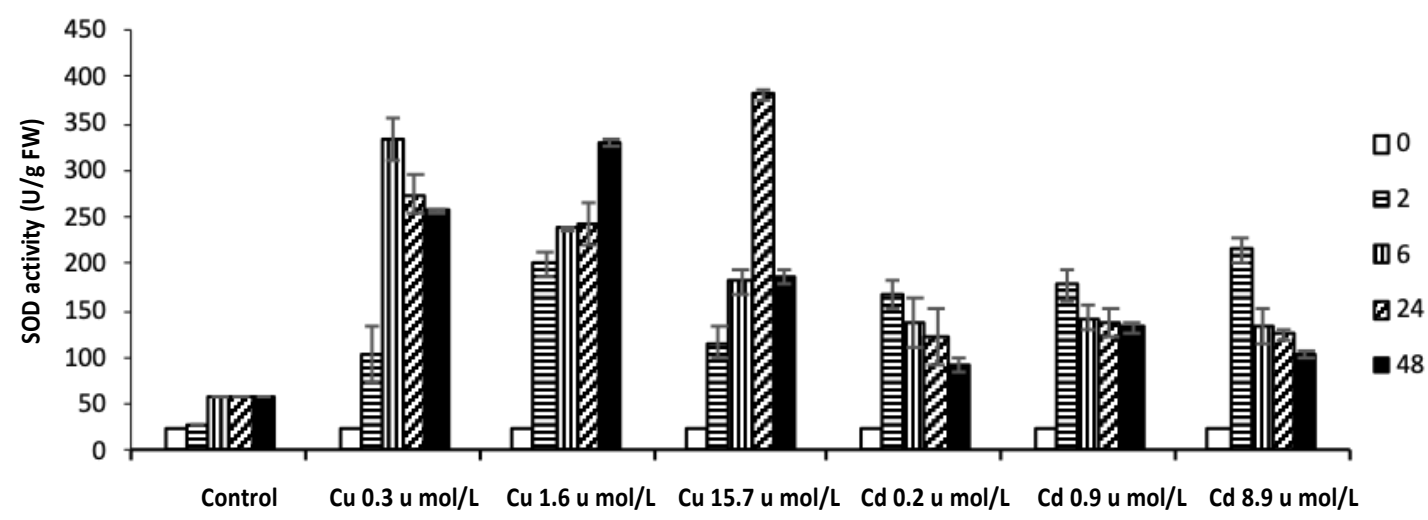

Figure 2. SOD enzyme activity of Chlorella sorokiniana after exposure to $\mathrm{Cu}$ and $\mathrm{Cd}$.

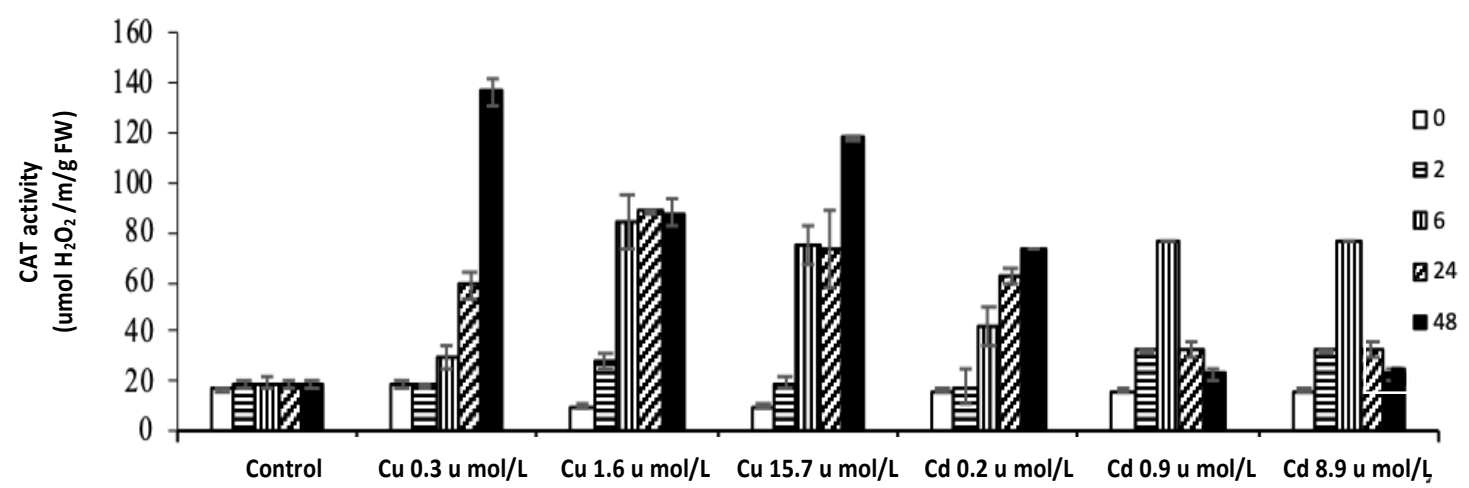

Figure 3. CAT enzyme activity of Chlorella sorokiniana after exposure to $\mathrm{Cu}$ and $\mathrm{Cd}$.

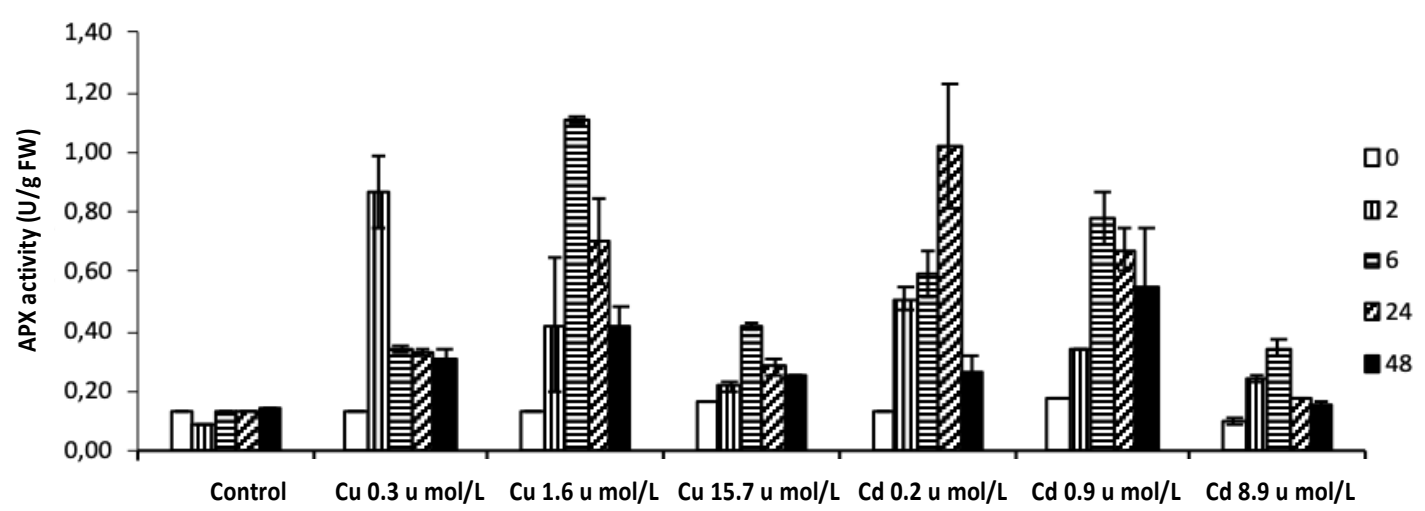

Figure 4. APX enzyme activity of Chlorella sorokiniana after exposure to $\mathrm{Cu}$ and $\mathrm{Cd}$. 


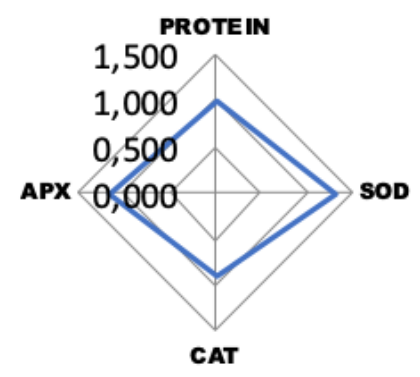

$\mathrm{IBR}=2.34$

A

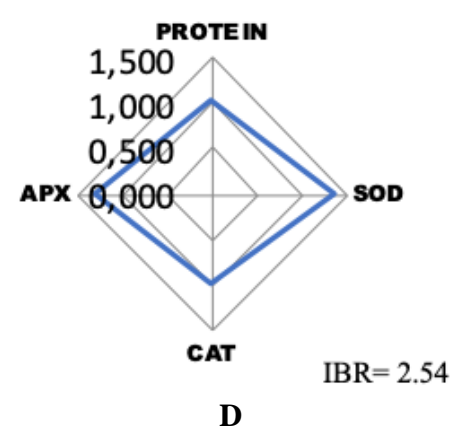

Figure 5. A. IBR value of $\mathrm{Cu} 0.3 \mu \mathrm{mol} \mathrm{L} \mathrm{L}^{-1}$, B. IBR value of $\mathrm{Cu} 1.6 \mu \mathrm{mol} \mathrm{L}^{-1}, \mathrm{C}$. IBR value of $\mathrm{Cu} 15.7 \mu \mathrm{mol} \mathrm{L}{ }^{-1}, \mathrm{D}$. IBR value of Cd 0.2 $\mu \mathrm{mol} \mathrm{L} \mathrm{L}^{-1}$, E. IBR value of $\mathrm{Cu} 0.9 \mu \mathrm{mol} \mathrm{L} \mathrm{L}^{-1}, \mathrm{~F}$. IBR value of $\mathrm{Cu} 8.9 \mu \mathrm{mol} \mathrm{\textrm {L } ^ { - 1 }}$

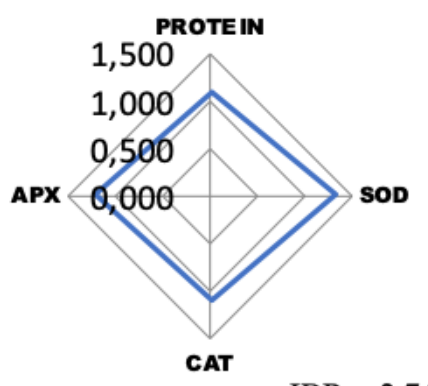

$\mathrm{IBR}=2.74$

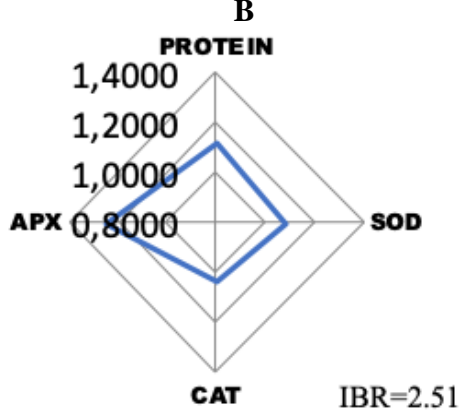

$\mathbf{E}$

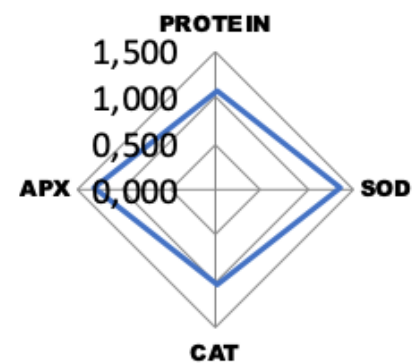

$\mathrm{IBR}=2.38$

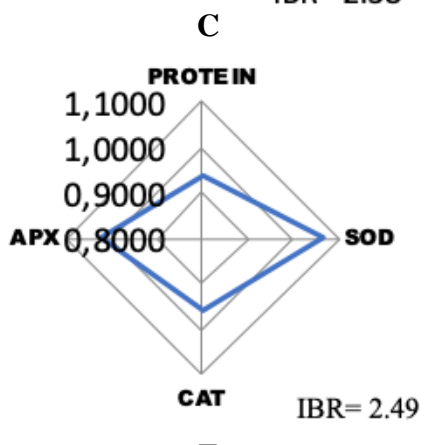

F
The first dimension had positive sentiment for protein content, SOD, and APX activity but it had negative sentiment for CAT activity. However, the second dimension only had positive sentiment for enzyme activity (protein content had negative sentiment in the second dimension). Not only analyzed groups variable and correlation between groups, MFA also could analyze individuals data. Figure 8 visualized 90 datasets based on values from the MFA program calculation. There were 90 individual data, a combination of 3 concentration of $\mathrm{Cu}$ and $\mathrm{Cd}$ metal exposed at 5 time periods in triplicate. Blueline referred to cadmium and yellow line referred to copper. Individual data number 61 had the highest value in the first dimension and individual data number 15 had the highest value in the second dimension.

\section{Discussion \\ Antioxidative defense mechanism}

Chlorella sorokiniana is used in this study because it shows higher absorption of metal than other algae. $C$. sorokiniana also shows less growth inhibition and oxidative stress response, which could possibly be caused by a more efficient antioxidant defense system, alleviating the stress induced by metal exposure (Hamed et al. 2017). Under no stress conditions, the formation and removal of reactive oxygen reactive (ROS) are balanced. However, under stress conditions, the formation of ROS exceeds the ability to eliminate them, so it is necessary to form enzymatic and non-enzymatic antioxidant compounds (Alscher et al. 2002). The first enzymatic compound formed to reduce ROS level is superoxide dismutase (SOD) enzyme. SOD will reduce ROS content by converting O2 •to hydrogen peroxide which easily passes through the cell plasma membrane. This hydrogen peroxide will later be converted into a less reactive compound by the CAT and APX enzymes.

As mentioned in results, there are significant differences in protein content, SOD, and APX activities after exposure to copper and cadmium. The only exception is CAT enzyme activity. The similar result also was found in Mallick (2004). CAT and APX have same substrate, hydrogen peroxide $\left(\mathrm{H}_{2} \mathrm{O}_{2}\right)$. Anjum et al. (2016) state that APX has higher affinity of $\mathrm{H}_{2} \mathrm{O}_{2}$ than CAT by using ascorbate acid as specific electron donor. Then ascorbate acid is used for reduction of $\mathrm{H}_{2} \mathrm{O}_{2}$ to $\mathrm{H}_{2} \mathrm{O}$ in chloroplast, cytosol, mitochondria, and peroxisome organelles. It means that when APX activity is getting higher, CAT enzyme activity is not showing same pattern because they work antagonized. Those three enzymes are related to each other to reduce levels of reactive oxygen species (ROS) in organisms. The relationship between three enzymes is shown in Figure 9.

\section{Integrated biomarker responses (IBR)}

Biomarkers responses are not always clear and easy to interpret because of their different pattern and visuals. This study used four biomarker responses (Protein content, SOD, CAT, and APX activities) and IBR value interpreted in each concentration of copper and cadmium (Table 3). Figure 5. A-F showed the score of protein content, SOD, CAT, and APX activity for each metal $(\mathrm{Cu}$ and $\mathrm{Cd})$ concentration. Those scores are drawn by using star plot and computerized as IBR.

Metal such cadmium has been known for its effect to increase antioxidative enzyme activities (Zhu et al. 2019). However, which enzyme has most sensitive response is still unknown. IBR could be one of tool to find out the question before. $\mathrm{Cu}$ and $\mathrm{Cd}$ concentration does not correlate with the 
increasing or decreasing of IBR value. Based on ANOVA and post hoc DMRT test, $\mathrm{Cu}$ and $\mathrm{Cd}$ do not have significant effect on CAT enzyme activity of $C$. sorokiniana. This result is updated with the IBR value that each concentration affects CAT enzyme activity differently (See Figure 5. A-F). This can occur because the IBR is a method that provides both a graphical synthesis of the different biomarker responses and a numeric value that integrates all these responses at once (Devin et al. 2014). The IBR value is calculated using selected biomarkers in a way of integrating responses and facilitate their interpretation (Iturburu et al. 2018).

\section{Multiple factor analysis}

Multiple factor analysis (MFA) is used to compare data sets structured in groups of variables in order to compare the groups and the conclusions to be drawn from the analysis of the data set by each group (Uher et al. 2017). In this study, the data are structured into three groups: one supplementary group (factor: metal) and two active groups (protein content and enzyme activity). Both active groups have strong contribution to dimension 1 whereas only enzyme activity had same contribution to dimension 2 (Figure 6). These results mean that there is a strong connection between protein content and enzyme activity. Change in protein content would affect enzyme production (Li et al. 2006). More explanation about protein content and enzyme activity is shown in Figure 7. Protein content and SOD have high values in dimension 1, and APX and SOD in dimension 2. Specific function of MFA besides showing the relationship between group variables is able to show the relationship between individuals in two dimensions. Individuals with similar profiles are close to each other on the factor map (Abdi and Williams 2010). Individual data number 61 has the highest protein content and SOD enzymes in dimension 1 and individual data number 15 has the highest APX and SOD enzyme activity (Figure 8). Variable which has the highest value in each dimension is the variable that most contributes to that dimension. The variables that most contribute to the first dimension and the second dimension are the most important variables that can explain the level of variability of data (Pagès 2002).

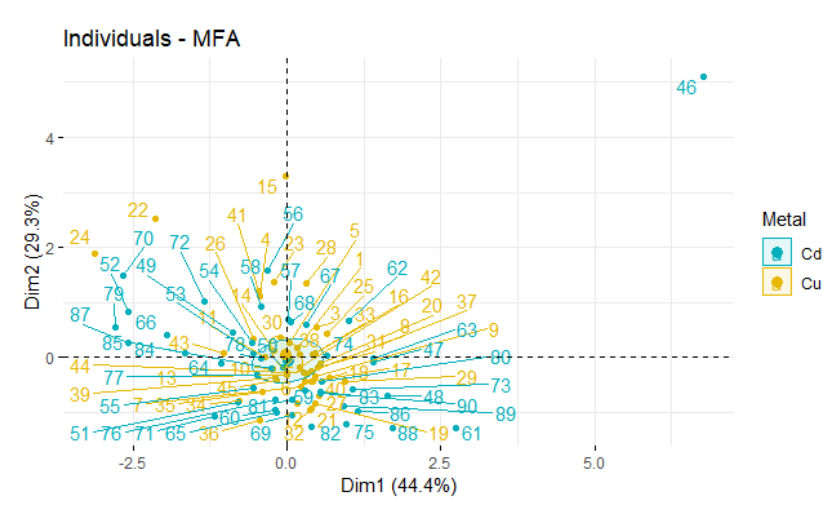

Figure 8. Individual data of each treatment and exposure time

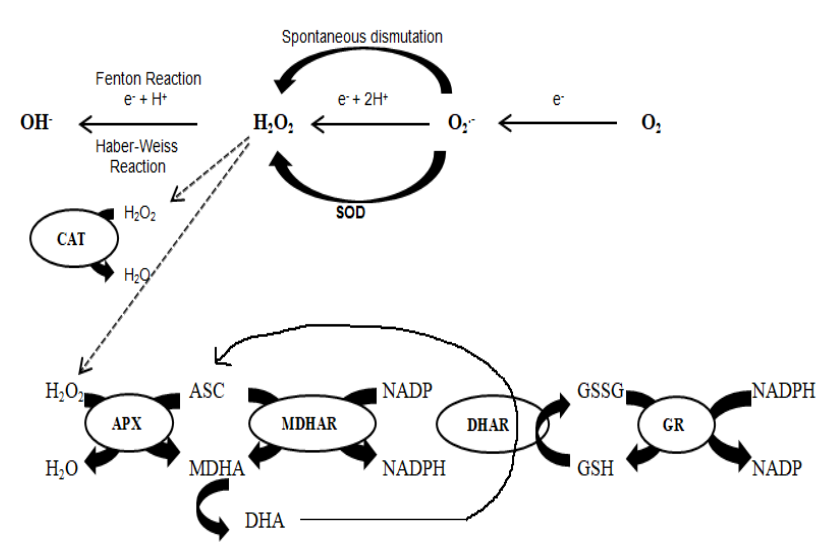

Figure 9. Defense mechanism against ROS (Anjum et al. 2015)
Figure 7. Relationship of quantitative variables with dimensions

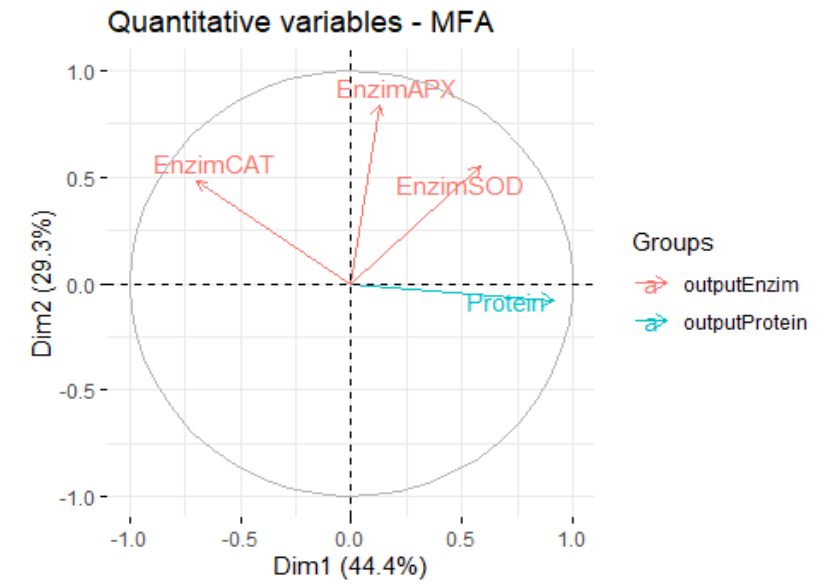

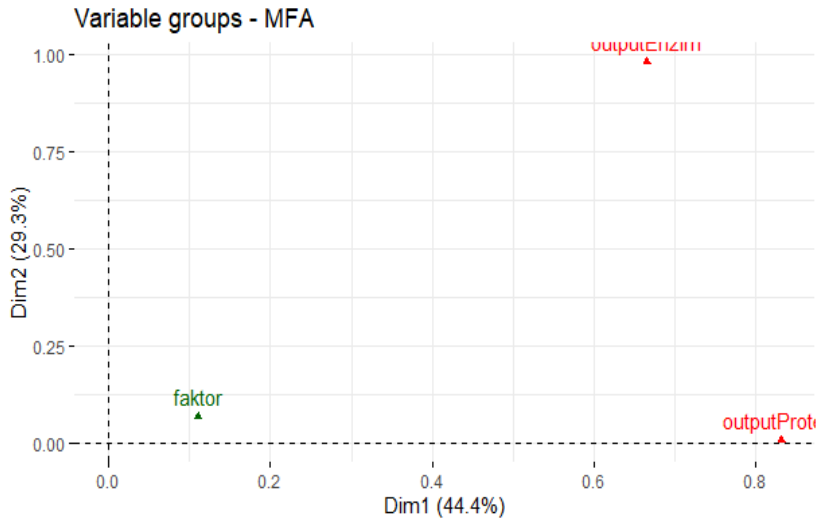

Figure 6. Representation of groups 


\section{ACKNOWLEDGEMENTS}

This work was supported by the Ministry of Research, Technology, and Higher Education of the Republic of Indonesia [Grant number 2579/UN1/DITLIT/DITLIT/LT/2019]. We would like to say big thanks to staff from the Laboratory of Ecology and Conservation, Falitma, Faculty of Biology, Universitas Gadjah Mada, Yogyakarta, Indonesia for providing facilities during the study.

\section{REFERENCES}

Abdi H, Williams LJ. 2010. Principal component analysis. John Wiley and Sons, Inc. WIREs Comp Stat 2: 433-459.

Aebi H, Lester P. 1984. Catalase in vitro. Meth Enzymol 121-126.

Alscher RG, Erturk N, Heath LS. 2002. Role of superoxide dismutase in controlling oxidative stress in plants. J Exp Bot 53 (372): 1331-1341. DOI. 10.1093/jexbot/53.372.1331

Anjum NA, Sharma P, Gill SS, Hasanuzzaman M, Khan EA, Kachhap K, Mohammed AA, Thangavel P, Devi GD, Vasudhevan P, Sofo A, Khan NA, Misra AN, Lukatkin AS, Singh HP, Pareira E, Tuteja N. 2016. Catalase and ascorbate peroxidase-representative $\mathrm{H}_{2} \mathrm{O}_{2}$ detoxifying heme enzymes in plants. Environ Sci Pollut Res 23: 19002-19029. DOI. 10.1007/s11356-016-7309-6

Beliaeff B, Burgeot T. 2002. Integrated biomarker response: A useful tool for ecological risk assessment. Environ Toxicol Chem 21 (6): 131622.

Bhattacharjee S. 2005. Reactive oxygen species and oxidative burst: Roles in stress, senescence and signal transduction in plant. Curr Sci 89 (7): 1113-1121.

Chang C, Sibley TH. 1993. Accumulation and transfer of copper by Oocystis pusilla. Bull Environ Contam Toxicol 50: 689-695.

Dat J, Vandenabeele S, Vranovaá E, Van Montagu M, Inzé D, Van Breusegem F. 2000. Dual action of the active oxygen species during plant stress responses. Cell Mol Life Sci 57 (5): 779-95. DOI: $10.1007 / \mathrm{s} 000180050041$

Devin S, Burgeo T, Giambérini L, Minguez L, Pain-Devin S. 2014. The integrated biomarker response revisited: Optimization to avoid misuse. Environ Sci Pollut Res Intl 21 (4): 2448-2454. DOI: 10.1007/s11356-013-2169-9

Elisabetta M, Gioacchino S. 2004. Copper-induced changes of non-protein thiols and antioxidant enzymes in the marine microalgae Phaeodactylum tricornutum. Plant Sci 167 (2): 289-296. DOI: 10.1016/j.plantsci.2004.04.001

Hamed SM, Selim S, Klock G, Abdelgawad H. 2017. Sensitivity of two green microalgae to copper stress: Growth, oxidative and antioxidants analyses. Ecotoxicol Environ Saf 144: 19-25. DOI: 10.1016/j.ecoenv.2017.05.048

Iturburu FG, Bertrand L, Mendieta JR, Améb MV, Menonea ML. 2018. An integrated biomarker response study explains more than the sum of the parts: Oxidative stress in the fish Australoheros facetus exposed to imidacloprid. Ecol Indicat 93: 351-357. DOI: 10.1016/j.ecolind.2018.05.019

Kasmiyati S. 2016. The tolerance mechanism of Sorghum bicolor (L.) Moench. against chrome stress: Physiological, anatomical, biochemical and molecular studies. [Dissertation]. Gadjah Mada University, Yogyakarta. [Indonesian]

Kim Y, Bong-Gyu M, Khan AL, Waqas M, Kim HH, Shahzad R, Imran M, Yun BW. 2017. Regulation of reactive oxygen and nitrogen species by salicylic acid in rice plants under salinity stress conditions. PLoS ONE 13 (3): e0192650. DOI: 10.1371/journal.pone.0192650

Le S, Pagès J. 2010. DMFA: Dual hierarchical multiple factor analysis. Commun Stat: Theory Methods 39: 483-492.

Le S, Josse J, Husson F. 2008. FactoMineR: An R package for multivariate analysis. J Stat Softw 25: 1-18.

Li M, Hu C, Zhu Q, Chen L, Kong Z, Liu Z. 2006. Copper and zinc induction of lipid peroxidation and effects on antioxidant enzyme activities in the microalgae Pavlova viridis. Chemosphere 62 (4): 565 572. DOI: 10.1016/j.chemosphere.2005.06.029

Lowry R, Rosebrough NJ, Farr AL, Randall RKJ. 1951. Protein Measurement with the Folin Phenol Reagent. Kluwer Academic Publishers, New York.

Mallick N. 2004. Copper induced oxidative stress in the Chlorophyceae microalga Chlorella vulgaris: Response of the antioxidant system. J Plant Physiol 161 (5): 591-597. DOI: 10.1078/0176-1617-01230

Marklund S, Marklund G. 1974. Involvement of the superoxide anion radical in the autoxidation of pyrogallol and a convenient assay for superoxide dismutase. Eur J Biochem 47 (3): 469-74. DOI: 10.1111/j.1432-1033.1974.tb03714.x

Matus I, Gonzales M, del Pozo A. 1999. Evaluation of phenotypic variation in a Chilean collection of garlic clones using multivariate analysis. Plant Genetic Resources Newsletter 117: 31-36.

Moussa IDB, Athmouni K, Chtouroul H, Ayadi H, Sayadil S, Dhoub A. 2017. Phycoremediation potential, physiological, and biochemical response of Amphora subtropica and Dunaliella sp. to nickel pollution. J Appl Phycol 30: 931-994. DOI:10.1007/s10811-0171315-Z

Nakano Y, Asada K. 1981. Hydrogen peroxide is scavenged by ascorbate peroxidase in spinach chloroplast. Plant Cell Physiol 22 (5): 867-880. DOI: 10.1093/oxfordjournals.pcp.a076232

Pagès J. 2002. Analyse Factorielle Multiple Appliquée Aux Variables Qualitatives et Aux Données Mixtes. Revue Statistique Appliquee 4: 5-37.

Sandoval MA, Flores MF, Narváez RA, López-Villada J. 2015. Phototrophic culture of Chlorella sp. using charcoal ash as an inorganic nutrient source. Algal Res 11: 368-374. DOI: 10.1016/j.algal.2015.07.008

Uher E, Besse J, Delaigue O, Husson F, Lebrun JD. 2017. Comparison of the metal contamination in water measured by diffusive gradient in thin-film (DGT), biomonitoring and total metal dissolved concentration at a national scale. Appl Geochem 88: 247-257. DOI: 10.1016/j.apgeochem.2017.05.003

Wang L, Kanga Y, Lianga S, Chena D, Zhanga Q, Zenga L, Luoa J, Jianga F. 2018. Synergistic effect of co-exposure to cadmium (II) and 4-n-nonylphenol on growth inhibition and oxidative stress of Chlorella sorokiniana. Ecotoxicol Environ Saf 154: 145-153. DOI: 10.1016/j.ecoenv.2018.02.039.

Zhu QL, Guo SN, Wen F, Zhang XL, Wang CC, Si LF, Zheng JL, Liu J. 2019. Transcriptional and physiological responses of Dunaliella salina to cadmium reveals time-dependent turn over of ribosome, photosystem, and ROS scavenging pathways. Aquat Toxicol 207: 153-162. DOI: 10.1016/j.aquatox.2018.12.007. 